\title{
The Untranslated Region of $\mu$-Opioid Receptor mRNA Contributes to Reduced Opioid Sensitivity in CXBK Mice
}

\author{
Kazutaka Ikeda, ${ }^{1,2}$ Toru Kobayashi, ${ }^{3}$ Tomio Ichikawa, ${ }^{3}$ Toshiro Kumanishi, ${ }^{3}$ Hiroaki Niki, ${ }^{1}$ and Ryoji Yano ${ }^{2}$ \\ Laboratories for ${ }^{1}$ Neurobiology of Emotion and ${ }^{2}$ Cellular Information Processing, Brain Science Institute, RIKEN, Wako, \\ Saitama 351-0198, Japan, and '3epartment of Molecular Neuropathology, Brain Research Institute, Niigata University, \\ Asahimachi, Niigata 951-8585, Japan
}

It is well known that there are individual differences in a sensitivity to analgesics. Several lines of evidence have suggested that the level of opioid-induced analgesia is dependent on the level of expression of the $\mu$-opioid receptor ( $\mu$-OR). However, the molecular mechanisms underlying the diversity of the level of the opioid receptor and the opioid sensitivity among individuals remain to be elucidated. In the present study, we analyzed the opioid-receptor genes of CXBK recombinant-inbred mice, which show reduced sensitivity to opioids. Northern blotting, nucleotide sequencing, and in situ hybridization histochemical analyses demonstrated that CXBK mice possessed $\mu$-OR mRNA with a normal coding region but an abnormally long untranslated region (UTR). In addition, the $\mu$-OR mRNA level in CXBK mice was less than in the control mice. Next, we pro- duced littermate mice that had inherited two copies of the wild-type $\mu$-OR gene, had inherited two copies of the CXBK $\mu$-OR gene, and had inherited both copies of the $\mu$-OR genes. In these mice, inheritance of the CXBK $\mu$-OR gene was well correlated with less $\mu$-OR mRNA and reduced opioid effects on nociception and locomotor activity. We conclude that the CXBK $\mu$-OR gene is responsible for the CXBK phenotypes. Because UTR differences are known to affect the level of the corresponding mRNA and protein and because UTRs are more divergent among individuals than coding regions, the present findings suggest that opioid sensitivity may vary, depending on different $\mu$-OR levels attributable to divergent UTR of $\mu$-OR mRNA.

Key words: CXBK mouse; $\mu$-opioid receptor; UTR; individual difference; analgesia; morphine
The CXBK mouse strain is a recombinant-inbred strain derived by full-sib mating from a cross between C57BL/6By and BALB/ cBy mice (Bailey, 1971). This strain has been used as a $\mu$-opioid receptor $(\mu$-OR)-deficient strain because CXBK mice have a low level of $\mu$-agonist binding sites (Moskowitz and Goodman, 1985) and display a reduced sensitivity to morphine and the $\kappa$-agonist U-50488 (Ikeda et al., 1999). For example, an important role of opioids in the analgesia induced by electroacupuncture and stress has been suggested because a lower level of electroacupuncture analgesia (Peets and Pomeranz, 1978) and lower levels of analgesia after defeat (Miczek et al., 1982) or swimming (Marek et al., 1988) are observed in CXBK mice, respectively. However, there is no molecular biological evidence that shows a deficiency of the $\mu$-OR gene in CXBK mice. Furthermore, we have demonstrated recently that $\mathrm{CXBK}$ mice display an apparently different phenotype from that of $\mu$-OR knock-out (KO) mice. This suggests that CXBK mice do not completely lack $\mu$-OR (Ikeda et al., 1999).

The main target of morphine is $\mu$-OR, and this is considered to be one of the most important molecules in opioid-induced analgesia. Mice that lack the $\mu$-OR gene $(\mu$-OR-KO) are insensitive to morphine (Matthes et al., 1996; Sora et al., 1997b; Tian et al., 1997; Loh et al., 1998) and are less sensitive to $\delta$ - and $\kappa$-agonists

Received Sept. 28, 2000; revised Nov. 17, 2000; accepted Nov. 27, 2000.

This research was supported by research grants from the Cooperative Research Program of the RIKEN Brain Science Institute and the Ministry of Education, Science, Sports, and Culture of Japan. We thank Dr. Raymond Kado, Dr. Tsuyoshi Koide, Dr. Nobuhiko Kojima, and Sheldon J. Moss for critical reading and discussion. We also thank Naomi Mihira, Yoshitaka Miyazaki, Tsutomu Oowada, and Yoshimasa Yamada for technical assistance.

Correspondence should be addressed to Kazutaka Ikeda, Department of Psychopharmacology, Tokyo Institute of Psychiatry, 2-1-8 Kamikitazawa, Setagaya, Tokyo 156-8585, Japan. E-mail: ikedak@prit.go.jp.

Copyright (c) 2001 Society for Neuroscience 0270-6474/01/211334-06\$15.00/0
(Sora et al., 1997a, 1999; Matthes et al., 1998) despite a normal expression of $\delta$ - and $\kappa$-opioid receptors in the brain (Kitchen et al., 1997; Sora et al., 1997b). Heterozygous mice with only one $\mu$-OR allele have $50 \%$ less $\mu$-OR protein than wild-type mice and show a reduced sensitivity to morphine (Sora et al., 1997b; Loh et al., 1998). This suggests that the amount of $\mu$-OR affects the sensitivity to opioid analgesics. Furthermore, polymorphisms in the $\mu$-OR gene have been found recently in humans, and the relationships between these polymorphisms and a vulnerability to drug abuse and dependence have been investigated (Bergen et al., 1997; Berrettini et al., 1997; Bond et al., 1998). The findings suggest that diversity of the $\mu$-OR gene may contribute to interindividual differences in a sensitivity to opioids.

Because the opioid sensitivity of CXBK mice is similar to that of $\mu$-OR-KO heterozygous mice (Ikeda et al., 1999), we focused on the $\mu$-OR gene as a candidate gene that could be responsible for the $\mathrm{CXBK}$ phenotypes. In the present study, we demonstrate that CXBK mice possess abnormally long $\mu$-OR mRNA and that the CXBK $\mu$-OR gene is correlated with a reduced $\mu$-OR mRNA level and opioid sensitivity.

\section{MATERIALS AND METHODS}

Animals. The mice were housed in aluminum cages with littermates of the same sex (up to five per cage) in an environment maintained at $23 \pm$ $1^{\circ} \mathrm{C}$, a relative humidity of $50 \pm 5 \%$, and with a $12 \mathrm{hr}$ light/dark cycle (lights on 7:00 A.M. to 7:00 P.M.). The mice had access to a standard commercial laboratory diet ad libitum (NMF; Oriental Yeast Co. Ltd., Tokyo, Japan) and water. CXBK mice were originally purchased from The Jackson Laboratory (Bar Harbor, ME). C57BL/6CrSlc (B6) and $\mathrm{BALB} / \mathrm{cCrSlc}(\mathrm{BALB} / \mathrm{c})$ mice were purchased from Japan SLC, Inc. (Shizuoka, Japan). The experimental procedures and housing conditions were approved by the Institutional Animal Care and Use Committee. All 
of the animals were cared for and treated humanely, in accordance with the animal experimentation guidelines of our institution.

Northern blot analyses. mRNAs were separately prepared from the brain of each naive adult male mouse (Messenger RNA Isolation kit; Stratagene, La Jolla, CA). RNA size markers were purchased from Novagen (Madison, WI). The RNAs were electrophoresed on $1 \%$ agarose gel containing formaldehyde and transferred to a nitrocellulose membrane (PROTRAN; Schleicher \& Schuell, Dassel, Germany) or a nylon membrane (Hybond-N+; Amersham Pharmacia Biotech, Uppsala, Sweden). The probes for $\mu$-, $\delta$-, and $\kappa$-opioid receptor mRNAs were prepared by PCR with $P f u$ DNA polymerase (Stratagene), pSPOR $\mu$, pSPOR $\delta$, and pSPOR $\kappa$ (Ikeda et al., 1995b, 1997) as the templates, respectively. The common pair of primers for fragments corresponding to the transmembrane $\mathrm{V}-\mathrm{V}$ II regions of the receptors $(\sim 100$ amino acids) were 5'-CT(C/G)ATCATC $(\mathrm{A} / \mathrm{T})(\mathrm{C} / \mathrm{T})(\mathrm{G} / \mathrm{T}) \mathrm{GT}(\mathrm{C} / \mathrm{G}) \mathrm{TG}(\mathrm{C} /$ T)TA-3' (sense primer) and 5'-GCGGATCCTTGAAGTT(C/T)TC(A/ G)TCCAG-3' (antisense primer). The hybridization was performed at $60^{\circ} \mathrm{C}$ for $\sim 20 \mathrm{hr}$ in a hybridization solution (ExpressHyb Hybridization Solution; Clontech, Palo Alto, CA $)$ with $\left[{ }^{32} \mathrm{P}\right]$-labeled probe $\left(2 \times 10^{6}\right.$ $\mathrm{cpm} / \mathrm{ml})$. The blots were washed at $42^{\circ} \mathrm{C}$ in $0.1 \times \mathrm{SSC}(150 \mathrm{~mm} \mathrm{NaCl}$ and $25 \mathrm{~mm}$ sodium citrate) containing $0.1 \%$ SDS. Autoradiography was performed and analyzed by using BAS-5000 Imaging Analyzer (Fujifilm, Tokyo, Japan). The values of photostimulated luminescence (PSL), which are proportional to the radioactivity in arbitrary measured areas (Amemiya et al., 1987), were compared in quantitative analyses. The membranes were dehybridized in $0.1 \times$ SSC solution containing $0.1 \%$ SDS at $100^{\circ} \mathrm{C}$ for $10 \mathrm{~min}$. Expressions of $\mu$-, $\delta$-, and $\kappa$-OR mRNAs were analyzed using the same membranes.

In situ hybridization. The probe for $\mu$-OR mRNA was a 45 -mer oligonucleotide complementary to a part of a $\mu$-OR cDNA sequence, including the initial methionine codon (Ikeda et al., 1996). The oligonucleotide was labeled with $\left[{ }^{33} \mathrm{P}\right] \mathrm{dATP}$ using terminal deoxyribonucleotidyl transferase (TaKaRa, Kyoto, Japan) and purified using a Sephadex G-25 Spin Column (Boehringer Mannheim, Indianapolis, IN). The specific activity of the probe was $5 \times 10^{8} \mathrm{dpm} / \mu \mathrm{g}$. In situ hybridization histochemistry was performed as described previously (Ikeda et al., 1998). Briefly, horizontal and sagittal sections of adult male B6 and CXBK mouse brains were placed on slides and fixed with $4 \%$ paraformaldehyde $/ 0.1 \mathrm{M}$ sodium PBS. The sections were hybridized in a hybridization solution containing $5 \times 10^{3} \mathrm{dpm} / \mu \mathrm{l}$ probe for $16 \mathrm{hr}$ at $42^{\circ} \mathrm{C}$. The slides were washed three times in $0.1 \times$ SSC $-0.1 \%$ Sarkosyl at $55^{\circ} \mathrm{C}$ for $40 \mathrm{~min}$, dehydrated, and analyzed by using BAS-5000 Imaging Analyzer (Fujifilm). Values of PSL were compared by quantitative analyses. Afterward, the slides were exposed to Hyperfilm- $\beta$-max (Amersham Pharmacia Biotech) for 2 weeks to obtain $x$-ray film images.

Nucleotide sequencing. The CXBK and B6 mouse brain cDNAs were synthesized with the corresponding mRNAs as the templates (1st Strand cDNA Synthesis kit; Clontech). Genomic DNAs were prepared from mouse tail or liver. DNA fragments were amplified by PCR with $P f u$ DNA polymerase. The PCR primers for $\mu$-OR cDNA were $5^{\prime}$-GCGCCTCCGTGTACTTCTAA-3' (sense primer) and 5'-GATGGCAGCCTCTAAGTTTA-3' (antisense primer). The nucleotide sequence of the PCR product was analyzed with the PCR primers and other primers as follows: 5'-AACCATGGACAGCAGCGCCG-3', 5'-GCCACTAGCACGCTGCCCTT-3', 5'-CAGTGGATCGAACTAACCACCAGCT-3', and 5'-GGATTTTGCTCAGAATGGTGGCATG-3' (Kaufman et al., 1995). The PCR primers for the $\mu$-OR genes $\left(5^{\prime}\right.$-flanking region to the translation starting site) were $5^{\prime}$-AATGCATTCTTGCTCCTCAAGGATC-3' (sense primer) and 5'-TCCCTGGGCCGGCGCTGCTGTCCAT-3' (antisense primer). The nucleotide sequence of the PCR product was analyzed with the PCR primers and other primers as follows: 5'AGTGGGGGCACATGAAACAGGCTTC-3', 5'-GAGGGTTATTAATGTTGTCCTTTAC-3', and 5'-GTTGTTACAAAGAAACTTAGAGTCT-3' (Liang et al., 1995). The nucleotide sequencing was conducted by using PRISM 310 genetic analyzer (Applied Biosystems, Foster City, CA).

Behavioral tests. Naive adult (6-15 weeks old) mice were used in all the experiments. Each mouse was tested in the daytime (not earlier than 8:00 A.M. and not later than 5:00 P.M.). After the mouse was weighed, the tail-flick, open-field, and hot-plate tests were performed (in that sequence) to examine the basal reactivities and activity. Morphine hydrochloride $(10 \mathrm{mg} / \mathrm{ml})$ was purchased from Takeda Chemical Industries Ltd. (Osaka, Japan). (1S-trans-)-3,4-dichloro- $N$-methyl- $N$-(2-[1-pyrrolidinyl]cyclohexyl)benzeneacetamide hydrochloride [(-)-U-50488] (Research Biochemicals, Natick, MA) was dissolved in distilled water, and the stock

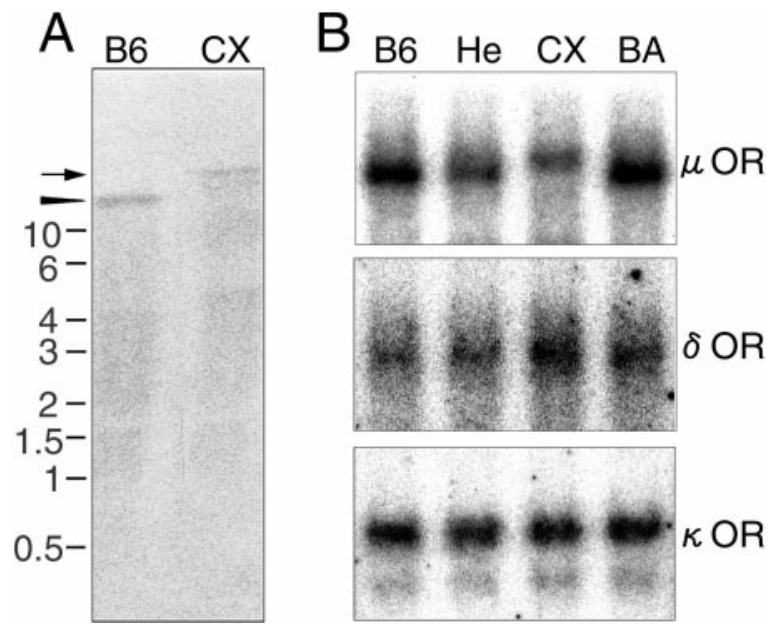

Figure 1. Northern blot analyses of CXBK mouse brain mRNAs. $A$, mRNAs $(1.5 \mu \mathrm{g})$ of B6 and CXBK $(C X)$ mouse brains were hybridized with cDNA probes for $\mu$-OR mRNA. The size of the detected band in the CX lane was estimated at $14.5 \mathrm{~kb}$ (arrow), whereas that in the B6 lane was at $12 \mathrm{~kb}$ (arrowhead). B, mRNAs $(4 \mu \mathrm{g})$ of B6, heterozygote $(\mathrm{He})$ between B6 and $\mathrm{CXBK}$, CXBK $(C X)$, and BALB/c $(B A)$ mouse brains were analyzed with cDNA probes for $\mu-, \delta$-, and $\kappa$-ORs. The sizes of $\mu$-OR probe-positive bands in the $B 6$ and $B A$ lanes were estimated at $12 \mathrm{~kb}$ and that in the $C X$ lane was at $14.5 \mathrm{~kb}$. The ratios of the signal intensities for the $\mu$-OR probe in the $H e, C X$, and $B A$ lanes to the intensity in the B6 lane were $0.75,0.6$, and 1.1 , respectively. The ratios of the signal intensity for the $\delta$-OR probe in the $\mathrm{He}, \mathrm{CX}$, and $\mathrm{BA}$ lanes to the intensity in the B6 lane were 1.1, 1.7, and 1.4, respectively. The signal intensities for the $\kappa$-OR probe in all lanes were even. The numbers next to the photographs indicate the RNA size in kilobases.

solution was stored at $-20^{\circ} \mathrm{C}$ until used. Each drug solution was diluted to $1 \mathrm{mg} / \mathrm{ml}$ with sterilized saline $(0.9 \% \mathrm{NaCl})$ on each experimental day. The drug solution was injected intraperitoneally to the mouse at a dose of $10 \mathrm{ml} / \mathrm{kg}$. The tail-flick, open-field, and hot-plate tests were performed 10,15 , and $20 \mathrm{~min}$ after the injection, respectively. The tail-flick test was performed according to the method of D'Amour and Smith (1941) with a slight modification (Ikeda et al., 1999). The cutoff time was $15 \mathrm{sec}$. The hot-plate test was performed according to the method of Woolfe and MacDonald (1944) with a slight modification (Ikeda et al., 1999). The temperature of the metal plate was adjusted to $52.0 \pm 0.2^{\circ} \mathrm{C}$. The latency, from the test start to the first jumping, was measured, and the cutoff time was $300 \mathrm{sec}$. The open-field test was performed as described previously (Ikeda et al., 1995a). The horizontal and vertical locomotions of the mouse were measured for $300 \mathrm{sec}$. In the present study, because the various kinds of locomotion were well correlated, the walking distance was used as the mouse locomotion. An ANOVA and Scheffe's F post hoc test were used to statistically analyze the between group data, with $p<$ 0.05 accepted as statistically significant.

\section{RESULTS}

\section{Abnormal $\mu$-OR mRNA in CXBK mice}

To investigate the expression of OR mRNAs in CXBK mice, we conducted Northern blot analyses (Fig. $1 A, B$ ). The CXBK mice had a large-sized (14.5 kb) $\mu$-OR mRNA in their brain, whereas the progenitor strain of mice, B6 mice, had $12 \mathrm{~kb} \mu$-OR mRNA. The heterozygotes between B6 and CXBK mice had both mRNAs, although the signal for the $14.5 \mathrm{~kb}$ mRNA was faint. The other progenitor stain of mice, BALB/c mice, had only $12 \mathrm{~kb}$ $\mu$-OR mRNA. The signal intensity for $\mu$-OR mRNA in CXBK mice was reduced to $\sim 60 \%$ of the intensity in $\mathrm{B} 6$ and $\mathrm{BALB} / \mathrm{c}$ mice, when equal amounts of brain mRNAs were electrophoresed and analyzed. Although the size of $\delta$-OR mRNA was the same in all strains, the signal intensity for $\delta$-OR mRNA in CXBK mice was higher than that in $\mathrm{B} 6$ and $\mathrm{BALB} / \mathrm{c}$ mice. The size of $\kappa-\mathrm{OR}$ 


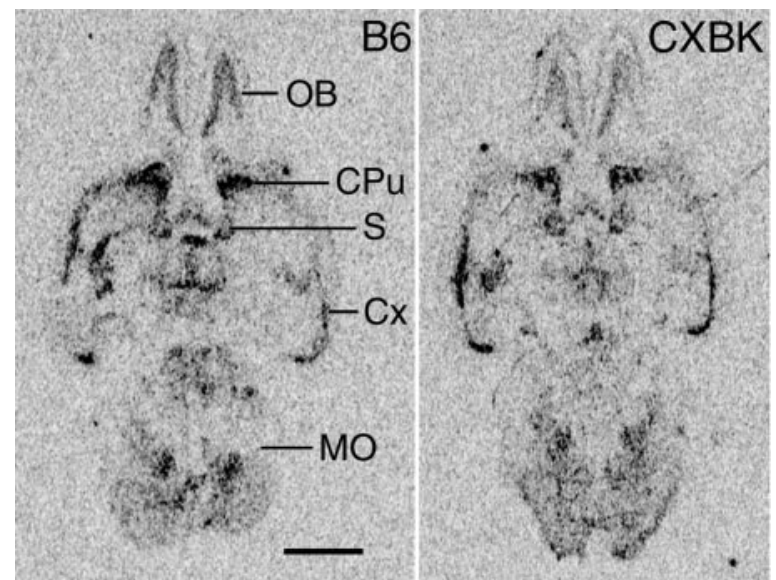

Figure 2. In situ hybridization showing the distribution of $\mu$-OR mRNA in the B6 and CXBK mouse brains. Positive images made from an x-ray film are displayed. The signal intensity for the $\mu$-OR mRNA in the CXBK mouse brain was lower than that in the B6 mouse brain $(\mathrm{p}<0.005$; $n=6$ for each group; Student's $t$ test). $C P u$, Caudate putamen; $C x$, cerebral cortex; $M O$, medulla oblongata; $O B$, olfactory bulb; $S$, septum. Scale bar, $2 \mathrm{~mm}$

mRNA and the signal intensity for the mRNA in all strains were not significantly different. The size difference in $\mu$-OR mRNA suggests that the $\mu$-OR gene in CXBK mice may be different from that of the progenitor strain mice.

\section{Distribution of $\mu$-OR mRNA in CXBK mice}

Next, by using in situ hybridization histochemistry, we compared the expression of the $\mu$-OR mRNA in the CXBK mouse brains with that in the B6 mouse brains (Fig. 2). In the CXBK mouse brain, the $\mu$-OR mRNA was expressed in a variety of brain regions in a similar manner to the $\mathrm{B} 6$ mouse brain. However, the signal intensity for the mRNA in the CXBK mouse brain was significantly lower ( $\sim 70 \%$ of that in the B6 mouse brain), which was consistent with the results of the Northern blot analyses. Similar results were obtained using sagittal sections of the B6 and CXBK mouse brains (data not shown). These results suggest that the expression level of the $\mu$-OR mRNA was homogeneously lower in the CXBK mouse brains.

\section{A nucleotide difference between $\mathrm{B} 6$ and CXBK $\mu$-OR genes}

A part (2184 bases; GenBank accession number AB047546) of the $\mu$-OR mRNA, including the entire coding region, was compared in B6 and CXBK mice (Fig. 3). The sequence of the coding region (1197 bases) of the $\mu$-OR mRNA in CXBK mice was identical to that in the $\mathrm{B} 6$ mice, indicating that the $\mu$-OR protein structure is normal, but the untranslated region (UTR) of the $\mu$-OR mRNA is abnormally long in CXBK mice. A sequence difference was not apparent in the examined 3'-UTR (726 bases), and there was only a single nucleotide sequence difference in the examined 5'-UTR (214 bases). This indicated that the difference in the size of the $\mu$-OR mRNA between the B6 and the CXBK mice would be in the unexamined UTR of the $\mu$-OR mRNA. We also compared a 5'-flanking region (1107 base pairs; GenBank accession number AB047547) with the translation starting site in the $\mathrm{B} 6$ and $\mathrm{CXBK} \mu$-OR genes. A sequence difference between them was not detected except that corresponding to the difference in the $5^{\prime}$-UTR. It was unlikely that the single nucleotide sequence difference caused whole CXBK phenotypes, because BALB/c

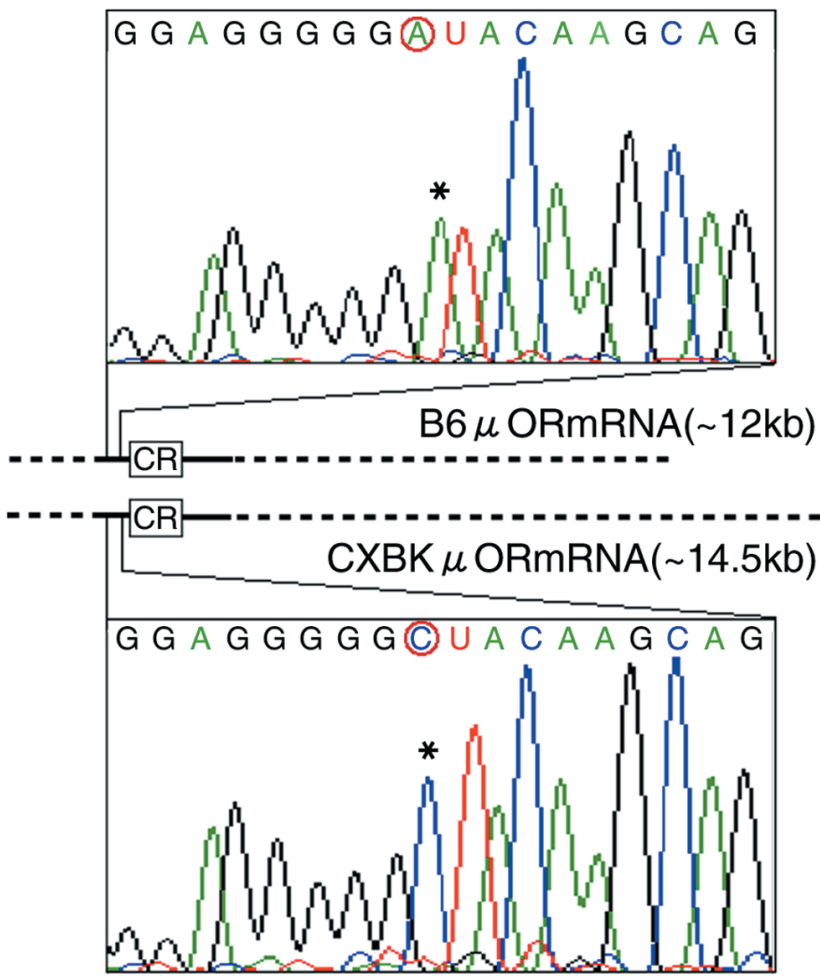

Figure 3. The nucleotide sequence differences in the $\mu$-OR mRNAs in the $\mathrm{B} 6$ and $\mathrm{CXBK}$ mouse brains. The $\mu$-opioid receptor mRNAs in the $\mathrm{B} 6$ and $\mathrm{CXBK}$ mouse brains are illustrated. The rectangles with $C R$ denote the coding regions of the $\mu$-OR mRNAs. The solid and broken lines denote the untranslated regions. The nucleotide sequences of the solid line were examined ( 214 base $5^{\prime}$-UTR and 726 base $3^{\prime}$-UTR). Chromatograms of nucleotide sequences of the regions containing a nucleotide sequence difference are shown. The difference was located at the 202 base upstream site from the translation starting site. Asterisks indicate the nucleotide sequence difference between the B6 and CXBK $\mu$-OR mRNAs.

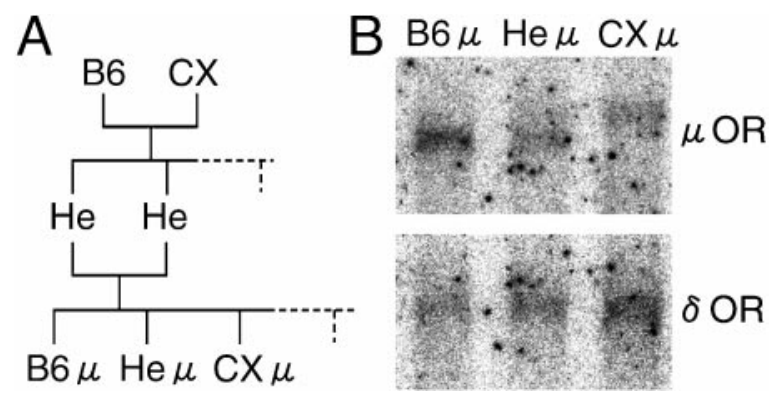

Figure 4. Littermate mice inheriting two copies of the B6 $\mu$-OR gene $(\mathrm{B} 6 \mu)$, mice inheriting one B6 $\mu$-OR gene and one CXBK $\mu$-OR gene $(\mathrm{He} \mu)$, and mice inheriting two copies of the CXBK $\mu$-OR gene $(\mathrm{CX} \mu)$. $A$, Pedigree indicating relations of $\mathrm{B} 6, \mathrm{CXBK}, \mathrm{He}, \mathrm{B} 6 \mu, \mathrm{CX} \mu$, and $\mathrm{He} \mu$ mice. Littermate mice were prepared by mating of heterozygotes $(\mathrm{He})$ between B6 and CXBK $(C X)$ mice. $B$, Northern blot analyses of littermate mouse brain mRNAs with cDNA probes for $\mu$ - and $\delta$-ORs. mRNAs $(1.3 \mu \mathrm{g})$ in the brains of male littermate mice were analyzed. The sizes of the $\mu$-OR probe-positive bands in the $B 6 \mu$ and $C X \mu$ lanes were estimated at 12 and $14.5 \mathrm{~kb}$, respectively. The ratios of the signal intensity for the $\mu$-OR probe in the $\mathrm{He} \mu$ and $C X \mu$ lanes to the signal intensity in the $B 6 \mu$ lane were 0.7 and 0.5 , respectively. The ratios of the signal intensity for the $\delta$-OR probe in the $H e \mu$ and $C X \mu$ lanes to the signal intensity in the $B 6 \mu$ lane were 1.2 and 1.9 , respectively. 
A
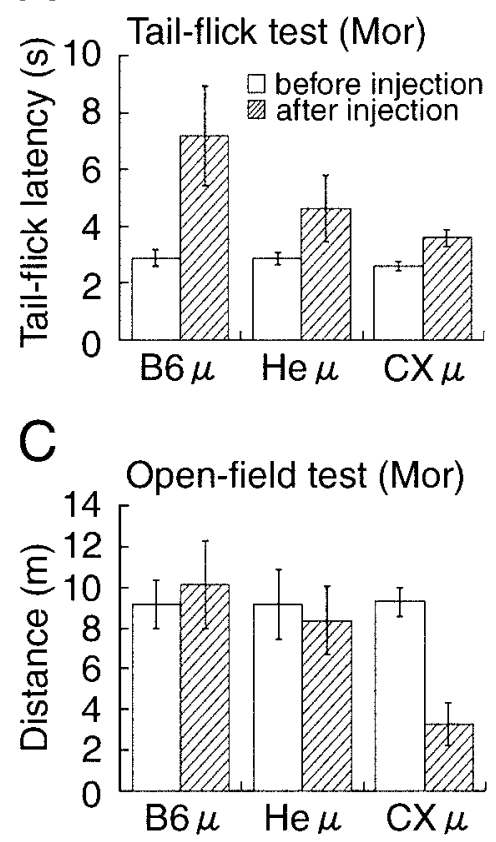

B

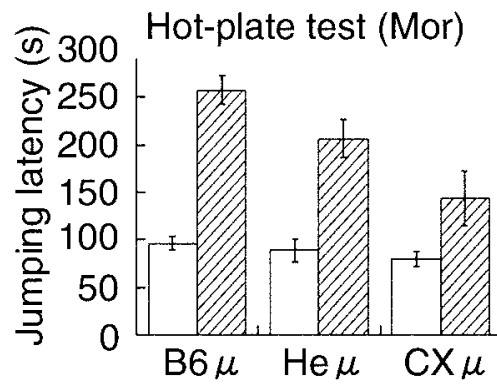

$\mathrm{D}$

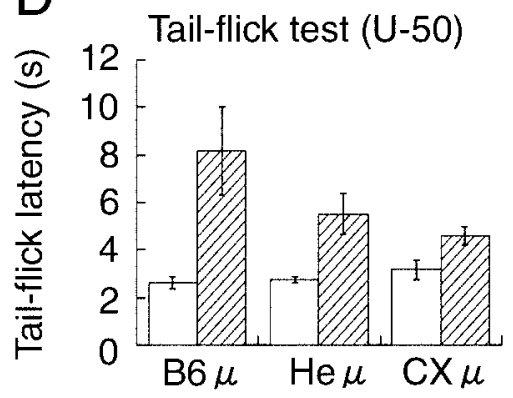

Figure 5. Reduced sensitivity to morphine and (-)-U-50488 of CX $\mu$ mice. The effects of morphine $(10 \mathrm{mg} / \mathrm{kg}$, i.p.) on nociception and locomotion in adult littermate $\mathrm{B} 6 \mu$, Не $\mu$, and $\mathrm{CX} \mu$ mice were investigated in tail-flick $(A)$, hot-plate $(B)$, and open-field $(C)$ tests $(n=10$ for each group). There was a significant difference in tail-flick latency between the B6 $\mu$ and $\mathrm{CX} \mu$ mice $(p<0.05$; repeated-measure ANOVA). In the hot-plate and open-field tests, there were significant interactions between the morphine effect and $\mu$-OR gene-type effect $(p<0.05$; repeated-measure ANOVA) when $\mathrm{CX} \mu$ and $\mathrm{B} 6 \mu$ mice were compared. $D$, Analgesia induced by (-)-U-50488 $(10 \mathrm{mg} / \mathrm{kg}$, i.p.) in adult littermate $\mathrm{B} 6 \mu, \mathrm{He} \mu$, and $\mathrm{CX} \mu$ mice was investigated in a tail-flick test ( $n=6$ for each group). There was significant interaction between the $(-)-\mathrm{U}-50488$ effect and the $\mu$-OR gene-type effect $(p<0.05$; repeatedmeasure ANOVA) when CX $\mu$ and B6 $\mu$ mice were compared. The white and striped bars represent the data before and after drug injections, respectively. All values are means \pm SEM. mice possessed the same nucleotide sequence in this region as CXBK mice (data not shown). However, the nucleotide difference made it possible to distinguish the CXBK-derived $\mu$-OR gene from the B6-derived $\mu$-OR gene in the following experiments.

\section{Mice inheriting two copies of the CXBK $\mu$-OR gene $(\mathbf{C X} \mu)$}

To understand the correlation between the CXBK $\mu$-OR gene and the $\mathrm{CXBK}$ phenotypes, we prepared littermates by mating heterozygotes between B6 and CXBK mice (Fig. 4A). These littermates were as follows: mice inheriting two copies of the B6 $\mu$-OR gene $(\mathrm{B} 6 \mu)$, mice inheriting the $\mathrm{CXBK} \mu$-OR gene $(\mathrm{CX} \mu)$, and mice inheriting one copy of the B6 $\mu$-OR gene and one copy of the $\mathrm{CXBK} \mu$-OR gene $(\mathrm{He} \mu)$. First, using these littermates, we conducted Northern blot analyses to clarify whether the differences in the size and amount of OR mRNAs in the CXBK mouse brains were attributable to the CXBK $\mu$-OR gene (Fig. $4 B$ ). The sizes of the $\mu$-OR mRNAs in B6 $\mu$ and $\mathrm{CX} \mu$ mice were estimated to be the same as the B6 and the CXBK mice, respectively. The signal intensities for the $\mu$ - and $\delta$-OR mRNAs in $\mathrm{CX} \mu$ mice were low and high, respectively, when compared with the signal intensities in B6 $\mu$ mice. He $\mu$ mice possessed both of these $\mu$-OR mRNAs in a similar manner to the heterozygotes between B6 and CXBK mice. These results suggest that the $\mathrm{CXBK} \mu$-OR gene caused the differences in the size and expression levels of the OR mRNAs in the CXBK mice.

\section{Reduced sensitivity to opioids of $\mathrm{CX} \boldsymbol{\mu}$ mice}

Second, using these littermates, we investigated whether the CXBK $\mu$-OR gene is associated with reduction of morphine effects in CXBK mice. We conducted tail-flick and hot-plate tests for morphine-induced analgesia (Fig. 5A,B) and an open-field test for morphine-induced hyperactivity (Fig. 5C). These mice responded to the heat stimuli with similar latencies and showed similar spontaneous activity when they were not given morphine. However, after intraperitoneal administration of $10 \mathrm{mg} / \mathrm{kg}$ morphine, $\mathrm{CX} \mu$ mice responded to heat stimuli with a significantly shorter latency than the littermates in both analgesic tests, indicating that the $\mathrm{CX} \mu$ mice showed lower morphine-induced analgesia. In the open-field test, $\mathrm{B} 6 \mu$ and $\mathrm{He} \mu$ mice walked similar distances before and after morphine administration, indicating that the decrease in locomotor activity attributable to habituation was counterbalanced by morphine-induced hyperactivity in these mice. In contrast, $\mathrm{CX} \mu$ mice walked significantly shorter distances after morphine administration than they did before morphine administration ( $p<0.001$; paired $t$ test), indicating that morphine failed to counterbalance the inhibiting effects of habituation on the locomotion of $\mathrm{CX} \mu$ mice. These results suggested that the reduced effects of morphine on nociception and locomotion in CXBK mice were correlated with the CXBK $\mu$-OR gene. Third, using these littermates, we investigated whether the CXBK $\mu$-OR gene caused reduced analgesic effects of (-)-U50488, a selective $\kappa$-agonist, in CXBK mice. In a tail-flick test, $\mathrm{CX} \mu$ mice responded to the heat stimulus with a shorter latency than the littermates after intraperitoneal administration of 10 $\mathrm{mg} / \mathrm{kg}(-)-\mathrm{U}-50488$ (Fig. 5D). This result suggest that the reduction of (-)-U-50488-induced analgesia in the CXBK mice was also associated with the $\mathrm{CXBK} \mu$-OR gene. These three correlations between the $\mathrm{CXBK} \mu$-OR gene and the CXBK phenotypes suggest that the $\mathrm{CXBK} \mu$-OR gene contributed to the CXBK phenotypes.

\section{DISCUSSION}

\section{The gene responsible for CXBK phenotypes}

When a novel phenotype appears during establishment of a recombinant-inbred strain, the phenotype is considered to be caused not by a single gene but by a combination of more than two genes (Bailey, 1981). However, in the present study, we found that $\mathrm{CXBK}$ and $\mathrm{CX} \mu$ mice possessed an abnormal-sized $\mu$-OR mRNA, whereas both the two progenitor mice and B6 $\mu$ mice possessed a normal-sized $\mu$-OR mRNA. This indicated that the CXBK $\mu$-OR gene is different from the $\mu$-OR gene of either of the progenitor mice. Furthermore, $\mathrm{CX} \mu$ mice displayed the CXBK phenotypes, a reduced $\mu$-OR mRNA level, and a reduced 
sensitivity to opioids. These findings suggest that the altered $\mu$-OR gene in CXBK mice is responsible for the CXBK phenotypes. Because the $\mu$-OR gene in CXBK mice seems to be different from either of the $\mu$-OR genes in the progenitor strains, it may be appropriate to classify the CXBK mouse strain into the mutant strains. Our present findings could provide essential bases for the previous studies using CXBK mice as $\mu$-OR-deficient mice (Peets and Pomeranz, 1978; Miczek et al., 1982; Marek et al., 1988). Further investigation of the sequence differences between CXBK and wild-type mice would reveal the molecular mechanisms underlying the reduced $\mu$-OR mRNA level and the reduced sensitivity to opioids in $\mathrm{CXBK}$ mice.

\section{OR mRNA levels in CXBK mice}

In the present study, we demonstrate a molecular mechanism that may underlie the reduced level of $\mu$-OR protein in CXBK mice. We found that the amount of $\mu$-OR mRNA in the CXBK mouse brains was reduced to $60 \%$ of the normal $\mu$-OR mRNA amount in the control B6 and BALB/c mouse brains. These results suggest that the $\mu$-OR protein level was reduced because of the reduced amount of $\mu$-OR mRNA in CXBK mice. Duttaroy et al. (1999), by using a RNase protection assay, have shown that the levels of $\mu$-OR mRNAs are similar in CXBK and control mice. This is inconsistent with our present results. This apparent discrepancy could be attributable to differences in the detection methods, because intact mRNAs can be selectively detected in Northern blot analyses, whereas partially degraded mRNAs are included in the experimental data in RNase protection assays. Therefore, we conclude that the amount of intact $\mu$-OR mRNA is reduced in $\mathrm{CXBK}$ mice. In addition, we observed that the amount of intact $\delta$-OR mRNA was increased in CXBK mice, a finding that is consistent with a previous report showing an increase of $\delta$-OR mRNA levels in several brain regions (Kest et al., 1998). Because the amounts of $\delta$ - and $\kappa$-OR mRNAs were reported to be unchanged in $\mu$-OR-KO mice (Kitchen et al., 1997; Sora et al., 1997b), there might be a specific mechanism for elevating the amount of $\delta$-OR mRNA in CXBK mice. Further investigations of the mechanism in $\mathrm{CXBK}$ mice may reveal interactions among the expression of $\mu$-, $\delta$-, and $\kappa$-OR mRNAs.

\section{Interindividual differences in analgesia}

Pain perception differs among individuals (Dellemijn, 1999; Mogil, 1999; Uhl et al., 1999), and the differences can be attributed to inherited factors as well as environmental factors. Several gene alterations associated with pathological pain perception have been identified by nucleotide sequencing or suggested by linkage analyses. These include mutations, in the tRNA ${ }^{\text {Leu(UUR) }}$ (Goto et al., 1990) or P/Q-type $\mathrm{Ca}^{2+}$ channel $\alpha 1$-subunit (Joutel et al., 1993; Ophoff et al., 1996) gene with familial migraine (Peroutka, 1998), mutations in the neurotrophic tyrosine kinase receptor type 1 (NTRK1) gene with congenital insensitivity to pain (Indo et al., 1996) and a region including the NTRK2 gene with hereditary sensory neuropathy type I (Nicholson et al., 1996). In addition to the genetic studies on pathological pain perception, differences in nonpathological pain perception have been studied by using interstrain differences in mice. For example, quantitative trait locus (QTL) analyses for basal nociceptive sensitivity and morphine-induced analgesia of the recombinant inbred strains between C57BL/6 (B6) and DBA/2, showed that the $\mu$-OR (Belknap et al., 1995), $\delta$-OR (Mogil et al., 1997), and serotonin-1B receptor (Mogil, 1999) genes were associated with the traits. Similar analyses revealed that three loci, including the
$\mu$-OR gene locus, were associated with morphine preference (Berrettini et al., 1994). However, nucleotide sequence differences in these genes have not yet been identified by the QTL methods. In the present study, by using a different approach of focusing on the OR genes, we found that the $\mu$-OR gene difference was associated with a reduced level of $\mu$-OR mRNA and a reduced sensitivity to opioids in $\mathrm{CXBK}$ mice. Considering the present findings together with the previous reports that show a reduced sensitivity to opioids in the heterozygous $\mu$-OR-KO mice with 50\% $\mu$-OR mRNA (Sora et al., 1997b; Loh et al., 1998), we propose that the low amount of $\mu$-OR mRNA causes the reduced sensitivity to opioids. Interindividual differences in opioid analgesia may be partly attributable to divergent $\mu$-OR mRNA levels because of $\mu$-OR gene differences.

\section{UTR differences and interindividual differences}

The stability, localization, and translation of mRNAs are known to be affected by the UTRs (Decker and Parker, 1995). It has been demonstrated in the nervous system that the $3^{\prime}$-UTR of the $\mathrm{Ca}^{2+}$ channel $\alpha_{1 \mathrm{~B}}$ mRNA mediates calcium-dependent stabilization of the mRNA (Brook et al., 1992) and that the $3^{\prime}$-UTR of the growth-associated protein of $43 \mathrm{kDa}$ mRNA is required for the stabilization of the mRNA in response to treatment with phorbol esters (Fu et al., 1992). In addition, recent studies have shown that alteration of UTR is related to several diseases. For example, expanded CTG repeat in the $3^{\prime}$-UTR of myotonic dystrophy protein kinase mRNA is responsible for myotonic dystrophy (Verkerk et al., 1991; Mahadevan et al., 1992; Gecz et al., 1996). The triplet repeats in the $5^{\prime}$-UTRs of fragile $X$ mental retardation-1 (FMR1) (Gu et al., 1996) and FMR2 (Tsai et al., 1997; Schorge et al., 1999) mRNAs are associated with fragile X syndrome. The present study, which demonstrates a reduced level of $\mu$-OR mRNA and a reduced sensitivity to opioids attributable to an abnormal UTR in CXBK mice, provides a novel aspect of the importance of the UTR. Because UTRs show little evolutionary conservation (Levitt, 1991), the resulting diversity of UTRs might be the molecular mechanisms for various interindividual differences. Analyses of UTRs could lead to identification of the gene responsible for diseases and individual differences and might contribute in the future to custom-made medical treatment.

\section{REFERENCES}

Amemiya Y, Wakabayashi K, Tanaka H, Ueno Y, Miyahara J (1987) Laser-stimulated luminescence used to measure x-ray diffraction of a contracting striated muscle. Science 237:164-168.

Bailey D (1981) Recombinant inbred strains and bilineal congenic strains. In: The mouse in biomedical research (Foster H, Small J, Fox J, eds), pp. 223-239. New York: Academic.

Bailey DW (1971) Cumulative effect or independent effect? Transplantation 11:419-422.

Belknap JK, Mogil JS, Helms ML, Richards SP, O’Toole LA, Bergeson SE, Buck KJ (1995) Localization to chromosome 10 of a locus influencing morphine analgesia in crosses derived from C57BL/6 and DBA/2 strains. Life Sci 57:PL117-PL124.

Bergen AW, Kokoszka J, Peterson R, Long JC, Virkkunen M, Linnoila M, Goldman D (1997) Mu opioid receptor gene variants: lack of association with alcohol dependence. Mol Psychiatry 2:490-494.

Berrettini WH, Ferraro TN, Alexander RC, Buchberg AM, Vogel WH (1994) Quantitative trait loci mapping of three loci controlling morphine preference using inbred mouse strains. Nat Genet 7:54-58.

Berrettini WH, Hoehe MR, Ferraro TN, DeMaria PA, Gottheil E (1997) Human mu opioid receptor gene polymorphisms and vulnerability to substance abuse. Addiction Biology 2:303-308.

Bond C, LaForge KS, Tian M, Melia D, Zhang S, Borg L, Gong J, Schluger J, Strong JA, Leal SM, Tischfield JA, Kreek MJ, Yu L (1998) Single-nucleotide polymorphism in the human mu opioid receptor gene alters beta-endorphin binding and activity: possible implications for opiate addiction. Proc Natl Acad Sci USA 95:9608-9613. 
Brook JD, McCurrach ME, Harley HG, Buckler AJ, Church D, Aburatani H, Hunter K, Stanton VP, Thirion JP, Hudson T, Sohn R, Zemelman B, Snell RG, Rundle SA, Crow S, Davies J, Shelbourne P, Buxton J, Jones C, Juvonen V, Johnson K, Harper PS, Shaw DJ, Housman DE (1992) Molecular basis of myotonic dystrophy: expansion of a trinucleotide (CTG) repeat at the $3^{\prime}$ end of a transcript encoding a protein kinase family member. Cell 69:385.

D'Amour F, Smith D (1941) A method for determining loss of pain sensation. J Pharmacol Exp Ther 72:74-79.

Decker CJ, Parker R (1995) Diversity of cytoplasmic functions for the 3' untranslated region of eukaryotic transcripts. Curr Opin Cell Biol $7: 386-392$.

Dellemijn P (1999) Are opioids effective in relieving neuropathic pain? Pain 80:453-462.

Duttaroy A, Shen J, Shah S, Chen B, Sehba F, Carroll J, Yoburn BC (1999) Opioid receptor upregulation in mu-opioid receptor deficient CXBK and outbred Swiss Webster mice. Life Sci 65:113-123.

Fu YH, Pizzuti A, Fenwick Jr RG, King J, Rajnarayan S, Dunne PW, Dubel J, Nasser GA, Ashizawa T, de Jong P, Wieringa B, Korneluk R, Perryman MB, Epstein HF, Caskey CT (1992) An unstable triplet repeat in a gene related to myotonic muscular dystrophy. Science 255:1256-1258.

Gecz J, Gedeon AK, Sutherland GR, Mulley JC (1996) Identification of the gene FMR2, associated with FRAXE mental retardation. Nat Genet 13:105-108

Goto Y, Nonaka I, Horai S (1990) A mutation in the tRNA(Leu)(UUR) gene associated with the MELAS subgroup of mitochondrial encephalomyopathies. Nature 348:651-653.

Gu Y, Shen Y, Gibbs RA, Nelson DL (1996) Identification of FMR2, a novel gene associated with the FRAXE CCG repeat and CpG island. Nat Genet 13:109-113.

Ikeda K, Araki K, Takayama C, Inoue Y, Yagi T, Aizawa S, Mishina M (1995a) Reduced spontaneous activity of mice defective in the epsilon 4 subunit of the NMDA receptor channel. Mol Brain Res 33:61-71.

Ikeda K, Kobayashi T, Ichikawa T, Usui H, Kumanishi T (1995b) Functional couplings of the delta- and the kappa-opioid receptors with the G-protein-activated $\mathrm{K}^{+}$channel. Biochem Biophys Res Commun 208:302-308

Ikeda K, Kobayashi T, Ichikawa T, Usui H, Abe S, Kumanishi T (1996) Comparison of the three mouse G-protein-activated $\mathrm{K}^{+}$(GIRK) channels and functional couplings of the opioid receptors with the GIRK1 channel. Ann NY Acad Sci 801:95-109.

Ikeda K, Kobayashi K, Kobayashi T, Ichikawa T, Kumanishi T, Kishida H, Yano R, Manabe T (1997) Functional coupling of the nociceptin/ orphanin FQ receptor with the G-protein-activated $\mathrm{K}^{+}$(GIRK) channel. Mol Brain Res 45:117-126.

Ikeda K, Watanabe M, Ichikawa T, Kobayashi T, Yano R, Kumanishi T (1998) Distribution of prepro-nociceptin/orphanin FQ mRNA and its receptor mRNA in developing and adult mouse central nervous systems. J Comp Neurol 399:139-151.

Ikeda K, Ichikawa T, Kobayashi T, Kumanishi T, Oike S, Yano R (1999) Unique behavioural phenotypes of recombinant-inbred CXBK mice: partial deficiency of sensitivity to $\mu$ - and $\kappa$-agonists. Neurosci Res 34:149-155.

Indo Y, Tsuruta M, Hayashida Y, Karim MA, Ohta K, Kawano T, Mitsubuchi H, Tonoki H, Awaya Y, Matsuda I (1996) Mutations in the TRKA/NGF receptor gene in patients with congenital insensitivity to pain with anhidrosis. Nat Genet 13:485-488.

Joutel A, Bousser MG, Biousse V, Labauge P, Chabriat H, Nibbio A, Maciazek J, Meyer B, Bach MA, Weissenbach J, Lathrop GM, Tournier-Lasserve E (1993) A gene for familial hemiplegic migraine maps to chromosome 19. Nat Genet 5:40-45.

Kaufman DL, Keith Jr DE, Anton B, Tian J, Magendzo K, Newman D, Tran TH, Lee DS, Wen C, Xia YR, Lusis AJ, Evans CJ (1995) Characterization of the murine mu opioid receptor gene. J Biol Chem 270:15877-15883.

Kest B, Beczkowska I, Franklin SO, Lee CE, Mogil JS, Inturrisi CE (1998) Differences in delta opioid receptor antinociception, binding, and mRNA levels between BALB/c and CXBK mice. Brain Res 805:131-137.

Kitchen I, Slowe SJ, Matthes HW, Kieffer B (1997) Quantitative autoradiographic mapping of mu-, delta- and kappa-opioid receptors in knockout mice lacking the mu-opioid receptor gene. Brain Res 778:73-88.

Levitt RC (1991) Polymorphisms in the transcribed 3' untranslated region of eukaryotic genes. Genomics 11:484-489.

Liang Y, Mestek A, Yu L, Carr LG (1995) Cloning and characterization of the promoter region of the mouse mu opioid receptor gene. Brain Res 679:82-88.

Loh HH, Liu HC, Cavalli A, Yang W, Chen YF, Wei LN (1998) mu
Opioid receptor knockout in mice: effects on ligand-induced analgesia and morphine lethality. Mol Brain Res 54:321-326.

Mahadevan M, Tsilfidis C, Sabourin L, Shutler G, Amemiya C, Jansen G, Neville C, Narang M, Barcelo J, O'Hoy K, Leblond S, EarleMacdonald J, de Jong PJ, Wieringa B, Korneluk RG (1992) Myotonic dystrophy mutation: an unstable CTG repeat in the $3^{\prime}$ untranslated region of the gene. Science 255:1253-1255.

Marek P, Yirmiya R, Liebeskind JC (1988) Strain differences in the magnitude of swimming-induced analgesia in mice correlate with brain opiate receptor concentration. Brain Res 447:188-190.

Matthes HW, Maldonado R, Simonin F, Valverde O, Slowe S, Kitchen I, Befort K, Dierich A, Le Meur M, Dolle P, Tzavara E, Hanoune J, Roques BP, Kieffer BL (1996) Loss of morphine-induced analgesia, reward effect and withdrawal symptoms in mice lacking the mu-opioidreceptor gene. Nature 383:819-823.

Matthes HW, Smadja C, Valverde O, Vonesch JL, Foutz AS, Boudinot E, Denavit-Saubie M, Severini C, Negri L, Roques BP, Maldonado R, Kieffer BL (1998) Activity of the delta-opioid receptor is partially reduced, whereas activity of the kappa-receptor is maintained in mice lacking the mu-receptor. J Neurosci 18:7285-7295.

Miczek KA, Thompson ML, Shuster L (1982) Opioid-like analgesia in defeated mice. Science 215:1520-1522.

Mogil JS (1999) The genetic mediation of individual differences in sensitivity to pain and its inhibition. Proc Natl Acad Sci USA 96:7744-7751.

Mogil JS, Richards SP, O'Toole LA, Helms ML, Mitchell SR, Belknap JK (1997) Genetic sensitivity to hot-plate nociception in DBA/2J and C57BL/6J inbred mouse strains: possible sex-specific mediation by delta2-opioid receptors. Pain 70:267-277.

Moskowitz AS, Goodman RR (1985) Autoradiographic analysis of mu1, mu2, and delta opioid binding in the central nervous system of C57BL/ 6BY and CXBK (opioid receptor-deficient) mice. Brain Res 360:108-116.

Nicholson GA, Dawkins JL, Blair IP, Kennerson ML, Gordon MJ, Cherryson AK, Nash J, Bananis T (1996) The gene for hereditary sensory neuropathy type I (HSN-I) maps to chromosome 9q22.1-q22.3. Nat Genet 13:101-104.

Ophoff RA, Terwindt GM, Vergouwe MN, van Eijk R, Oefner PJ, Hoffman SM, Lamerdin JE, Mohrenweiser HW, Bulman DE, Ferrari M, Haan J, Lindhout D, van Ommen GJ, Hofker MH, Ferrari MD, Frants RR (1996) Familial hemiplegic migraine and episodic ataxia type- 2 are caused by mutations in the $\mathrm{Ca}^{2+}$ channel gene CACNL1A4. Cell 87:543-552.

Peets JM, Pomeranz B (1978) CXBK mice deficient in opiate receptors show poor electroacupuncture analgesia. Nature 273:675-676.

Peroutka SJ (1998) Genetic basis of migraine. Clin Neurosci 5:34-37.

Schorge S, Gupta S, Lin Z, McEnery MW, Lipscombe D (1999) Calcium channel activation stabilizes a neuronal calcium channel mRNA. Nat Neurosci 2:785-790.

Sora I, Funada M, Uhl GR (1997a) The mu-opioid receptor is necessary for [D-Pen2,D-Pen5] enkephalin-induced analgesia. Eur J Pharmacol 324:R1-R2.

Sora I, Takahashi N, Funada M, Ujike H, Revay RS, Donovan DM, Miner LL, Uhl GR (1997b) Opiate receptor knockout mice define mu receptor roles in endogenous nociceptive responses and morphine-induced analgesia. Proc Natl Acad Sci USA 94:1544-1549.

Sora I, Li XF, Funada M, Kinsey S, Uhl GR (1999) Visceral chemical nociception in mice lacking mu-opioid receptors: effects of morphine, SNC80 and U-50,488. Eur J Pharmacol 366:R3-R5.

Tian M, Broxmeyer HE, Fan Y, Lai Z, Zhang S, Aronica S, Cooper S, Bigsby RM, Steinmetz R, Engle SJ, Mestek A, Pollock JD, Lehman MN, Jansen HT, Ying M, Stambrook PJ, Tischfield JA, Yu L (1997) Altered hematopoiesis, behavior, and sexual function in mu opioid receptor-deficient mice. J Exp Med 185:1517-1522.

Tsai KC, Cansino VV, Kohn DT, Neve RL, Perrone-Bizzozero NI (1997) Post-transcriptional regulation of the GAP-43 gene by specific sequences in the $3^{\prime}$ untranslated region of the mRNA. J Neurosci 17:1950-1958.

Uhl GR, Sora I, Wang Z (1999) The mu opiate receptor as a candidate gene for pain: polymorphisms, variations in expression, nociception, and opiate responses. Proc Natl Acad Sci USA 96:7752-7755.

Verkerk AJ, Pieretti M, Sutcliffe JS, Fu YH, Kuhl DP, Pizzuti A, Reiner O, Richards S, Victoria MF, Zhang FP, Eussen BE, van Ommen GJB, Blonden LAJ, Riggins GJ, Chastain JL, Kunst CB, Galjaard H, Caskey CT, Nelson DL, Oostra BA, Warren ST (1991) Identification of a gene (FMR-1) containing a CGG repeat coincident with a breakpoint cluster region exhibiting length variation in fragile $\mathrm{X}$ syndrome. Cell 65:905-914.

Woolfe G, Macdonald A (1944) The evaluation of the analgesic action of pethidine hydrochloride (demerol). J Pharmacol Exp Ther 80:300-307. 